UDC $615.12: 339.137 .2$

DOI: $10.24959 /$ sphhcj.17.68

I. V. BondARIEVA, V. V. MALYI

National University of Pharmacy

\title{
THE STUDY OF ORGANIZATIONAL CHANGES AS A FACTOR OF SUSTAINABILITY OF PHARMACEUTICAL ORGANIZATIONS
}

In today's rapidly changing environment to remain competitive, maintain a high quality level of the customer's service and a proper technological level it is necessary to carry out organizational changes for a pharmaceutical organization.

Aim. To study the process of organizational changes in pharmaceutical organizations.

Materials and methods. To study the process of the change management the expert survey of 89 managers of pharmacies was conducted.

Results. The main factors that affect the activities of the organization, the types of changes, and the main aspects of changes have been determined. The most important advantages (improvement of the quality of the employees' labor; improvement of teamwork and achievement of goals) and limitations (increase of the payback period; emphasis on the group processes rather than on the activity indicators; difficulty of assessing results) of organizational changes specific to pharmacies have been found.

Conclusions. The results obtained can be used when implementing organizational changes in pharmaceutical organizations.

Key words: organizational changes; pharmaceutical organizations; limitations of organizational changes.

\section{І. В. БОНДАРєВА, В. В. МАЛИЙ}

\section{ВИВЧЕННЯ ОРГАНІЗАЦІЙНИХ ЗМІН ЯК ФАКТОРА СТІЙКОСТІ ФАРМАЦЕВТИЧНИХ ОРГАНІЗАЦІЙ}

Сьогодні в умовах динамічного зовнішнього середовища фармацевтичним організаціям для підвищення конкурентоспроможності, підтримки високого рівня якості обслуговування і належного технологічного рівня необхідно імплементувати організаційні зміни.

Мета: дослідження процесу організаційних змін у фармацевтичних організаціях.

Матеріали та методи. Для вивчення процесу управління змінами було проведено експертне опитування 89 завідувачів аптек.

Результати. Визначено основні фактори, що впливають на діяльність організації, типи та основні аспекти організаційних змін. Встановлено найбільш важливі переваги (поліпшення якості праці співробітників; поліпшення роботи в команді і досягнення цілей) та обмеження (збільшення періоду окупності; акцент на групові процеси, а не на показники діяльності; складність оцінки результатів) організаційних змін, характерних для аптек.

Висновки. Отримані результати можуть бути використані при запровадженні організаційних змін у фармацевтичних організаціях.

Ключові слова: організаційні зміни; фармацевтичні організації; обмеження організаційних змін.

\section{И. В. БОНДАРЕВА, В. В. МАЛЫЙ}

\section{ИЗУЧЕНИЕ ОРГАНИЗАЦИОННЫХ ИЗМЕНЕНИЙ КАК ФАКТОРА УСТОЙЧИВОСТИ ФАРМАЦЕВТИЧЕСКИХ ОРГАНИЗАЦИЙ}

Сегодня в условиях динамичной внешней среды фармацевтическим организациям для повышения конкурентоспособности, поддержания высокого уровня качества обслуживания и надлежащего технологического уровня необходимо имплементировать организационные изменения.

Цель: исследование процесса организационных изменений в фармацевтических организациях.

Материалы и методы. Для изучения процесса управления изменениями был проведен экспертный опрос 89 заведующих аптек.

Результаты. Определены основные факторы, влияющие на деятельность организации, типы и основные аспекты организационных изменений. Установлены наиболее важные преимущества (улучшение качества работы сотрудников; улучшение работы в команде и достижение целей) и ограничения (увеличение периода окупаемости; акцент на групповые процессы, а не на показатели деятельности; сложность оценки результатов) организационных изменений, характерных для аптек.

Выводы. Полученные результаты могут быть использованы при внедрении организационных изменений в фармацевтических организациях.

Ключевые слова: организационные изменения; фармацевтические организации; ограничения организационных изменений. 
Statement of the problem. In today's rapidly changing environment, the accelerated pace of life, and a variety of innovations in a successful technology an organization must be able to respond to these factors. To remain competitive, maintain a high quality level of the customer's service and a proper technological level it is necessary to carry out organizational changes. Modern organization operates in an increasingly unpredictable environment, so it should be able to respond quickly to unforeseen events. Over the years, changes have produced a large number of methods to adapt to the changing economic environment. The main changes are: improvement of organization of work, modernization of production processes, development and introduction of fundamentally new equipment, expansion of the market, and changeover to new products that are in high demand.

Analysis of recent research and publications. Today we can speak about great scientific contribution in development of theoretical and methodological principles of formation and implementation of organizational changes by works of Kotvitska A. A., Mnushko Z. M., Nemchenko A. S., Posylkina O. V., Pestun I. V., Ponomarenko M. S., Tolochko V. M., Khomenko V. M., etc. Each scientist offers the own vision of the process of their implementation.

Identification of aspects of the problem unsolved previously. However, in the new economic conditions, it is not enough to solve problems in traditional ways for effective functioning and stable development of the necessary changes concerning the structure and the company's management system as a whole. The main administrative error in most organizations is the use of out-dated management systems, which do not allow properly to be tuned to the needs. On this basis it can be concluded that in today's economic environment businesses must deliberately carry out organizational changes for the sake of survival and flexibility to respond to rapidly changing market conditions. Therefore, the topicality of the problem of studying organizational changes as a factor of sustainability of pharmaceutical organizations led the scientific and practical relevance of this work.

Objective statement of the article. The aim was to study the process of organizational changes in pharmaceutical organizations. There were the following tasks of our research: to analyze the advantages and limitations of organizational changes in pharmacies; determine the main factors that affect the activities of the organization, the types of changes, and the main aspects of changes.

Materials and methods. The questionnaire survey, systematic and logical analysis were used.

Presentation of the main material of the research. Organizational change is a process of switching of the organization as a system from one stable state to another using the existing ideas and concepts.

Changes in the organization are divided into two basic types:

- Natural (unplanned) changes. Changes that occur without advance this goal are the result of exposure to the external environment.

- Artificial (planned) changes. Changes that are made specifically for the purpose of adapting the organization to the environment strengthen the management system. If the organization is subjected only to unplanned changes, it is a sign of mismanagement, manifestation of unwillingness or lack of foresight and willingness to react on the opportunities and challenges at the right moment. But do not forget that planning cannot completely eliminate the need to unplanned changes as well. Despite this, the planned changes help the organization to adequately prepare for unexpected changes and minimize the situation where it is important to take responsible decisions in a short time $[1,2]$.

Any change should be carefully thought out and dictated by the necessity of removal of emerging problems with the purpose of increasing the organization's functioning efficiency. The enterprises' necessity in the changes arises up both under action of external factors and internal factors, such as low efficiency, high costs of production, financial problems, ineffective organizational structure, as well as the necessity of rationalization of production.

John Kotter concluded that the change process should be performed in several successive stages. They are:

1) to create an atmosphere of urgency (having studied the market situation, the competitive position of the company to identify and analyze actual and potential crises, opportunities); 

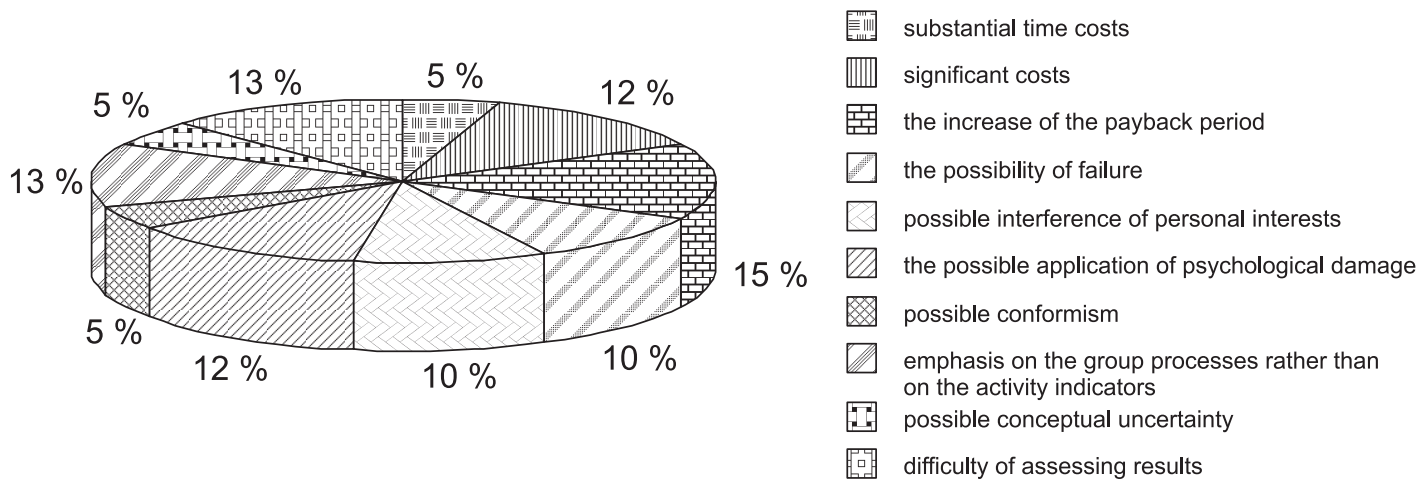

Fig. The limitations of organizational changes inherent Ukrainian pharmacies

2) to form a powerful team of reformers (combining the efforts of influential employees, change agents, encouraging the participants of the work teams formed);

3) to create a vision (creating an image of a desired future in order to increase the activity of employees; developing a strategy to achieve the vision);

4) to promote a new vision (using accessibility of presentation, metaphors, analogies, examples, models of a new behavior reform team);

5) to create the conditions for implementation of the new vision in life (eliminating the obstacles blocking the new behavior, changing the structure and duties contrary to the new vision, encouraging creativity and willingness to take risks).

6) to plan and achieve immediate results (planning required first steps, rewarding and promoting early successes);

7) to fix the achievements and expand the transformation (creating an atmosphere of confidence to new approaches; changing staffing and spending reshuffle, spreading the successful experience throughout the organization);

8) to institutionalize new approaches (formalizing the rules of conduct; building a relationship between results and rewards; creating conditions for development of quality of new employees).

Unfortunately, blindly following the sequence of steps is unlikely to lead to success because transformation of the organization is very complex process that cannot be squeezed into the framework of a certain sequence of actions [3].

To study the process of the change management in the Ukrainian pharmacies we conducted an expert survey of 89 managers of pharmacies. The main aspects of changes in the pharmacies studied were determined.
The advantages of organizational changes inherent the Ukrainian pharmacies were analyzed. It was found that managers of pharmacies identified the most important advantages for pharmacies, which included improvement of the quality of the employees' labor, improvement of teamwork and achievement of goals; it was $17.7 ; 17.4$ and 14.5 points, respectively.

During our research the analysis of limitations of organizational changes inherent the Ukrainian pharmacies was carried out. It was found that a lot of answers of the managers of pharmacies were related to the increase of the payback period; emphasis on the group processes rather than on the activity indicators; difficulty of assessing results, these issues were $15 \%, 13 \%, 13 \%$ of the respondents' answers, respectively.

Today, managers recognize the inevitability of changes due to the accelerating pace of change and the unpredictability of developments in the external environment. Here are some key factors accelerating a change:

- Demanding buyers. Due to the stiff competition in most areas the buyers receive the best service, the best quality and a greater variety of goods and services. Cycles of life of goods and services decline, and more and more new niches appear at the markets. To maintain the competitiveness the organization has to offer the best service, quality and is able to create new markets or penetrate to them;

- Globalization. Competition becomes of global scale, so that the buyers have an opportunity to buy any goods around the world. Goods and services move freely around the world; sources of supply have increased considerably; 
- Technology. Information technology seriously affect the way goods are produced and services are provided as it is managed within organizations and delivery to the market of goods and services;

- Human factor. Of decisive importance is the need to attract, retain and motivate employees [4].

It is under the influence of these factors there is an unstable and unpredictable environment due to which the organization has to change constantly adapting to the environment. The organization may also provoke changes in the external environment, developing and releasing new products and technologies, which become dominant and are in high demand, to the market. Successful organizations today operate through constant changes. The effective change management in the technical, economic, political, demographic and social spheres allows organizations to successfully adapt to the changing environment.

The changes are based on the depth and nature, ranging from the operation of immutable to a complete restructuring of the organization. Each type of change is caused by changes occurring in the external environment, as well as the strengths and weaknesses of the organization.

Quite often objects of development become many organizational parameters, such as structure and processes; manufacturing and information technology; organizational culture; human resources.

Changes should be organically «integrate» into the existing structure of the organization without disturbing its integrity. To do this, different channels to connect to the organizational integrity are used: the target determination, the system of organizational values, and the formal structure of restructuring. Thus, the processes of changes in organizations require serious management and provide the necessary exposure $[1,2,5]$.

Each transformation has certain conditions that weaken the resistance of the members of the organization and to ensure a positive outcome.

An essential precondition for the start of any changes in the organization is the fact that these changes will contribute to development of its strategy as long-term survival of the organization is based on the quality of its strategy. In a situation when the conversion is only indirectly affect the strategy, there are doubts as to the necessity and usefulness. The main prerequisite update is introduction of understanding what changes are necessary for normal, healthy development into the consciousness of people in the organization, and people should always be prepared for them. Change does not necessarily indicate that the organization is in the critical condition, but they must be carried out not for their own sake, but to the benefit of all employees.

Another prerequisite is the ideological formation and development of a new system of common values constituting one of the foundations of security and stability of the organization. It is necessary to take into account the individual values of its members. Then, employees will become more active to achieve common goals.

Another ideological prerequisite for the successful implementation of the changes is the recognition of the unique personality of each employee of the organization and education of feeling of confidence to the performers, attitude towards them as the main creative force, not simply as a staff.

The latest update is the ideological premise of creating and maintaining the organization of the necessary atmosphere, ensuring good relations in the team and the elimination of internal barriers.

An important institutional prerequisite update is the presence of clear goals and strategies, broad involvement of ordinary performers to the solution of the maximum number of tasks facing the organization, including those related to unforeseen situations.

In addition, a prerequisite for successful implementation of the changes is a guarantee of employment to all supporters, and the more ardent adherents of reforms, who are usually the qualified personnel. At the same time, by employees, officer's hindrance strongly needs to get rid of, but layoffs are justified only in the most severe crisis. It is necessary to develop an effective staff incentive system, which ensures that the personnel is interested in the changes, allowing both rewarding achievements 
and being in relation to the attention of management, providing with the public recognition.

\section{Conclusions}

1. The main factors that affect the activities of the organization, the types of changes, and the main aspects of changes have been determined.

2. The analysis of advantages of organizational changes inherent pharmacies has been conducted. It has been found that the most important advantages inherent pharmacies are improvement of the quality of labor, improve- ment of teamwork and achievement of goals with $17.7,17.4$ and 14.5 points, respectively.

3. The limitations of organizational changes specific for pharmacies have been analyzed. It has been found that a lot of answers of the managers of pharmacies were related to the increase of the payback period; emphasis on the group processes rather than on the activity indicators; difficulty of assessing results, these issues were $15 \%, 13 \%, 13 \%$ of the respondents' answers, respectively.

Conflicts of Interest: authors have no conflict of interest to declare.

\section{References}

1. Bondarieva, I. V. Research basic changes that occurred in the work of Ukrainian pharmacies / I. V. Bondarieva // Perspective trends in scientific research - 2015 : collection of conference papers of Intern. ScientificPract. Conf. (17-22 October, 2015, Bratislava, Slovac Republic). In 2 v. V. 2. - K. : Centre of Educational Literature, 2015. - P. 102-103.

2. Malyi, V. V. Theoretical approaches to change management in pharmaceutical organizations: the main stages and methods process of implementation changes / V. V. Malyi, I. V. Bondarieva, I. V. Timaniuk // The 6th European Conference on Biology and Medical Sciences : collection of conference papers of Intern. Conf. (June 10, 2015, Austria, Vienna). - Vienna : «East West» Association for Advanced Studies and Higher Education GmbH, 2015. - P. 131-136.

3. Kotter, John P. That's Not How We Do It Here!: A Story about How Organizations Rise and Fall--and Can Rise Again / John P. Kotter, Holger Rathgeber. - Portfolio, 2016. - 176 p.

4. Mnushko, Z. N. The features of process by changes management on production pharmaceutical enterprises of Ukraine / Z. N. Mnushko, I. V. Pestun, I. V. Bondareva // Nauka i studia. - 2012. - № 1 (46). - P. 64-70.

5. Malyi, V. V. The study of basic reasons managed and unmanaged processes of crisis development / V. V. Malyi, I. V. Bondarieva, I. V. Timaniuk // Актуальные вопросы образования, науки и производства в фармации: сборник матер. научно-практ. конфер., Ташкент, 19-20 нояб. 2015 г. - Ташкент, 2015. - С. 235-236.

\section{References}

1. Bondarieva, I. V. (2015). Research basic changes that occurred in the work of Ukrainian pharmacies. Proceeding from The Perspective trends in scientific research - 2015 '15: International Scientific and Practical Conference. (pp. 102-103). Kiev: Centre of Educational Literature.

2. Malyi, V. V., Bondarieva, I. V., Timaniuk, I. V. (2015). Theoretical approaches to change management in pharmaceutical organizations: the main stages and methods process of implementation changes. Proceeding from The 6th European Conference on Biology and Medical Sciences '15: International Conference. (pp. 131-136). Vienna: «East West» Association for Advanced Studies and Higher Education GmbH.

3. Kotter, J. P., Rathgeber, H. (2016). That's Not How We Do It Here!: A Story about How Organizations Rise and Fall - and Can Rise Again. Portfolio, 176.

4. Mnushko, Z. N., Pestun, I. V., Bondareva, I. V. (2012). The features of process by changes management on production pharmaceutical enterprises of Ukraine. Nauka i studia, 1 (46), 64-70.

5. Malyi, V. V., Bondarieva, I. V., Timaniuk, I. V. (2015). The study of basic reasons managed and unmanaged processes of crisis development. Proceeding from The topical issues of education, science and production in pharmacy '15: Nauchno-prakticheskaia konferentsiia (19-20 noiabria 2015 goda) - Scientific and Practical Conference. (pp. 235-236). Tashkent. 
Information about authors:

Bondarieva I. V., Candidate of Pharmacy (Ph.D.), associate professor of the Department of Pharmaceutical Marketing and

Management, National University of Pharmacy (http://orcid.org/0000-0003-2415-9780). E-mail: iryna.bondarieva@gmail.com Malyi V. V., Doctor of Pharmacy (Dr. habil.), professor, head of the Department of Pharmaceutical Marketing and Management, National University of Pharmacy (http://orcid.org/0000-0002-6028-1890). E-mail: malyi.vladimir@gmail.com

Відомості про авторів:

Бондарєва I. B., кандидат фармацевтичних наук, доцент кафедри фармацевтичного маркетингу та менеджменту,

Національний фармацевтичний університет (http://orcid.org/0000-0003-2415-9780). E-mail: iryna.bondarieva@gmail.com Малий В. В., доктор фармацевтичних наук, професор, завідувач кафедри фармацевтичного маркетингу та менеджменту, Національний фармацевтичний університет (http://orcid.org/0000-0002-6028-1890). E-mail: malyi.vladimir@gmail.com Сведения об авторах:

Бондарева И. В., кандидат фармацевтических наук, доцент кафедры фармацевтического маркетинга и менеджмента, Национальный фармацевтический университет (http://orcid.org/0000-0003-2415-9780). E-mail: iryna.bondarieva@gmail.com Малый B. B., доктор фармацевтических наук, профессор, заведующий кафедрой фармацевтического маркетинга и менеджмента, Национальный фармацевтический университет (http://orcid.org/0000-0002-6028-1890).

E-mail: malyi.vladimir@gmail.com 